Research, Society and Development, v. 9, n. 10, e7199108992, 2020

(CC BY 4.0) | ISSN 2525-3409 | DOI: http://dx.doi.org/10.33448/rsd-v9i10.8992

\title{
Management of gummosis in citrus with potassium phosphite
}

Fosfito de potássio no manejo da gomose em citros

Fosfito de potasio en el manejo de la gomosis de los citricos

Received: 10/02/2020 | Reviewed: 10/10/2020 | Accept: 10/14/2020 | Published: 10/16/2020

\section{Dalilla Carvalho Rezende}

ORCID: https://orcid.org/0000-0001-5572-4901

Instituto Federal de Educação, Ciência e Tecnologia do Sul de Minas Gerais, Brasil

E-mail: dalilla.rezende@ifsuldeminas.edu.br

Dayson Fernando Ribeiro Brandão

ORCID: https://orcid.org/0000-0003-0720-5060

Stoller do Brasil, Brasil

E-mail: dayson.brandao@gmail.com

Simone Cristiane Brand

ORCID: https://orcid.org/0000-0002-0916-5448

PlantCare Pesquisa Agrícola Ltda, Brasil

E-mail: scbrand@alumni.usp.br

Silvia Blumer

ORCID: https://orcid.org/0000-0002-6893-7639

Centro Universitário da Fundação de Ensino Octávio Bastos, Brasil

E-mail: silviablumer@gmail.com

Sérgio Florentino Pascholati

ORCID: https://orcid.org/0000-0002-9690-9694

Universidade de São Paulo, Brasil

E-mail: sfpascho@usp.br

Natália Moreira Mafra

ORCID: https://orcid.org/0000-0003-0083-0867

Instituto Federal de Educação, Ciência e Tecnologia do Sul de Minas Gerais, Brasil

E-mail: natalia.mafra@ifsuldeminas.edu.br

\begin{abstract}
This work aimed to evaluate the potassium phosphite-based commercial product, Phytogard ${ }^{\circledR}$, as a complementary tool for the management of gummosis in citrus. Seedlings of tangerine
\end{abstract}


'Sunki' were sprayed at concentrations $0 ; 0.5 ; 2$ and $5 \mathrm{~mL} \mathrm{~L}^{-1}$ of Phytogard ${ }^{\circledR}$ and subsequently inoculated with zoospores of Phytophthora nicotianae. The disease incidence was reduced by $84 \%$ in plants sprayed at the concentration $0.5 \mathrm{~mL} \mathrm{~L}^{-1}$ and the plants sprayed at concentrations of 2 and $5 \mathrm{~mL} \mathrm{~L}^{-1}$ showed zero disease incidence. There was increased an production of fresh matter of shoot and roots in plants sprayed and inoculated with the pathogen compared to unsprayed plants. Plants sprayed with Phytogard ${ }^{\circledR}$ and inoculated with the pathogen showed lower values for total phenols, enzyme activity for phenylalanine ammonia-lyase and peroxidase and for total protein content in root tissues compared to non-inoculated plants. There was higher activity of the enzyme $\beta$ 1.3-glucanase in root tissues of plants inoculated with the pathogen that received the product at the concentration of $2 \mathrm{~mL} \mathrm{~L}^{-1}$. The results of this study showed that the potassium phosphite-based product Phytogard ${ }^{\circledR}$ has potential for the control of Phytophthora nicotianae in seedlings of tangerine 'Sunki'. However, it is not possible to conclude that this control occurs through resistance induction.

Keywords: Citrus sunki; Alternative control; Phytophthora nicotianae; Phytopathology.

\section{Resumo}

O objetivo do trabalho foi avaliar o produto comercial à base de fosfito de potássio, Phytogard $\AA$, como ferramenta no manejo da gomose em citros. Mudas de tangerina 'Sunki' foram pulverizadas nas concentrações $0 ; 0,5 ; 2$ e $5 \mathrm{~mL} \mathrm{~L}^{-1}$ de Phytogard® e posteriormente inoculados com zoósporos de Phytophthora nicotianae. A incidência da doença foi reduzida em $84 \%$ nas plantas pulverizadas com o produto na concentração de $0,5 \mathrm{~mL} \mathrm{~L}^{-1}$ e nas plantas pulverizadas nas concentrações de 2 e $5 \mathrm{~mL} \mathrm{~L}^{-1}$ não houve incidência de doença. Houve um aumento na produção de matéria fresca da parte aérea e raízes em plantas pulverizadas e inoculadas com o patógeno em comparação com plantas não pulverizadas. As plantas pulverizadas com Phytogard® e inoculadas com o patógeno apresentaram menores valores de fenóis totais, atividade enzimática de fenilalanina amônia-liase e guaiacol peroxidase e no teor de proteínas totais nas raízes em comparação com as plantas não inoculadas. Houve maior atividade da enzima $\beta$ 1.3-glucanase nas raízes de plantas inoculadas com o patógeno que recebeu o produto na concentração de $2 \mathrm{~mL} \mathrm{~L}^{-1}$. Os resultados deste estudo mostraram que o produto à base de fosfito de potássio Phytogard® possui potencial para o controle de Phytophthora nicotianae em mudas de tangerina 'Sunki'. Porém, não é possível concluir que esse controle ocorra por meio da indução de resistência.

Palavras-chave: Citrus sunki; Controle alternativo; Phytophthora nicotianae; Fitopatologia. 


\section{Resumen}

El objetivo de este estudio fue evaluar el producto comercial a base de fosfito de potasio, Phytogard ${ }$, como herramienta para el manejo de la gomosis de los citricos. Las plántulas de mandarina 'Sunki' fueron rociadas a concentraciones de $0 ; 0,5 ; 2$ y $5 \mathrm{~mL} \mathrm{~L}^{-1}$ de Phytogard® y posteriormente inoculadas con zoosporas de Phytophthora nicotianae. La incidencia de la enfermedad se redujo en un $84 \%$ en las plantas rociadas con el producto a concentraciones de $0,5 \mathrm{~mL} \mathrm{~L}^{-1}$ y en las plantas rociadas a concentraciones de 2 y $5 \mathrm{~mL} \mathrm{~L}^{-1}$ no hubo incidencia de enfermedad. Hubo un aumento en la producción de materia fresca de la parte aérea y las raíces en las plantas rociadas e inoculadas con el patógeno en comparación con las plantas no rociadas. Las plantas rociadas con Phytogard® y inoculadas con el patógeno mostraron valores más bajos de fenoles totales, actividad enzimática de la fenilalanina amonia liasa y la guaiacol peroxidasa y contenido total de proteínas en las raíces en comparación con las plantas no inoculadas. Hubo mayor actividad enzimática $\beta$ 1,3-glucanasa en las raíces de las plantas inoculadas con el patógeno que recibieron el producto en una concentración de $2 \mathrm{~mL}$ $\mathrm{L}^{-1}$. Los resultados de este estudio mostraron que el producto a base de fosfito de potasio Phytogard ${ }^{\circledR}$ tiene el potencial de controlar la Phytophthora nicotianae en las plántulas de mandarina 'Sunki'. Sin embargo, no es posible concluir que este control se produce mediante la inducción de resistencia.

Palabras clave: Citrus sunki; Control alternativo; Phytophthora nicotianae; Fitopatología.

\section{Introduction}

One of most significant production sectors of the Brazilian agribusiness, the citrus segment, grants Brazil the leading position as the world's major orange and orange juice producer. However, the citrus production faces numerous problems related to occurrences of pests and diseases that limit production and compromise food safety. Among the various diseases that attack citrus worldwide, the gummosis disease, caused by species of the genus Phytophthora, is among the most important one (Graham \& Timmer, 1994). Phytophthora spp. produces resistance structures that make the elimination of these soil pathogens virtually impossible after their introduction in the area. Exclusion constitutes the primary control method of diseases caused by species of this genus (Feichtenberger et al., 2005). According to Fundecitrus (2004), in addition to elimination, other control measures are recommended such as the use of resistant rootstocks and avoidance of planting in areas of high humidity and waterlogging. The curative control of this disease is difficult and costly and can be 
accomplished with chemical control by using fosetyl-Al or phosphites (Feichtenberger et al., 2005).

Many studies show phosphites as one of potential alternatives for the control of various diseases, especially those caused by oomycetes. These products are inorganic salts originating from phosphorous acid $\left(\mathrm{H}_{3} \mathrm{PO}_{3}\right)$ used as an alternative to phosphates in soil fertilization (Dalio et al., 2012). Phosphorus (P) is an essential element for the functioning of the plant cell, as it is component of nucleic acids and enzymes, in addition to mediating important metabolic processes in energy production. Many commercial products have the phosphite as a phosphorus source, however, despite being absorbed by leaves and roots, phosphites are not oxidized or metabolized by plants (Guest \& Grant, 1991; Carswell et al., 1996; Varadarajan et al., 2002) and therefore they are useless as a P source (Carswell et al., 1996; Forster et al., 1998; Schroetter et al., 2006). The great advantage of using phosphites refers to fungicidal action to the plant without causing toxicity (Cohen \& Coffey, 1986). Phosphite-based products are marketed in Brazil as foliar fertilizers for the control of various diseases (Nascimento et al., 2008).

Protecting plants against pathogens, such as the Phytophthora species, is still a challenge (Dalio et al., 2014). Treatment of plants mainly in nursery conditions constitutes a breakthrough against different Phytophthora species and other pathogens of importance in Brazil, using products less toxic to the environment, such as phosphites. Therefore, this work aimed to evaluate the potassium phosphite-based commercial product, Phytogard ${ }^{\circledR}$, as a complementary tool for the management of gummosis in citrus.

\section{Methodology}

\subsection{Obtaining and maintaining isolates of Phytophthora spp.}

The isolate of $P$. nicotianae was provided by Dr. Ronaldo Dalio (APTA/IAC). The isolate was kept in a carrot-agar-medium (200 $\mathrm{g}$ carrots and $20 \mathrm{~g}$ agar L $\mathrm{L}^{-1}$ of distilled water) at $28^{\circ} \mathrm{C}$ in the dark to provide conditions for pathogen growth.

\subsection{Potassium phosphite}

The source of potassium phosphite used was the product Phytogard ${ }^{\circledR}$, marketed by Stoller do Brasil LTDA. This product has $28 \% \mathrm{P}_{2} \mathrm{O}_{5}$, whose source is phosphorous acid and $26 \%$ of $\mathrm{K}_{2} \mathrm{O}$, with density of $1.51 \mathrm{~g} \mathrm{~L}^{-1}$ and $\mathrm{pH} 7$. 
Research, Society and Development, v. 9, n. 10, e7199108992, 2020

(CC BY 4.0) | ISSN 2525-3409 | DOI: http://dx.doi.org/10.33448/rsd-v9i10.8992

The Phytogard ${ }^{\circledR}$ concentrations used in this assay and their respective values in potassium phosphite are detailed in Table 1.

Table 1. Phytogard $®$ concentrations and their respective values in potassium phosphite.

\begin{tabular}{cc}
\hline $\begin{array}{c}\text { Phytogard }^{\circledR} \\
\left(\mathrm{mL} \mathrm{L}^{-1}\right)\end{array}$ & $\begin{array}{c}\text { Potassium phosphite } \\
\left(\mathrm{g} \mathrm{L}^{-1}\right)\end{array}$ \\
\hline 0 (control) & 0 \\
0.5 & 0.24 \\
$2^{*}$ & 0.95 \\
5 & 2.38 \\
\hline
\end{tabular}

* Dose recommended by the manufacturer as foliar fertilizer for citrus seedlings Source: Authors.

To determine water consumption, we used seedlings of tangerine 'Sunki' with approximately 50 days of age. The seedlings were transferred to plastic vials $(8 \mathrm{~mL})$ and filled with sterile distilled water. The tubes were sealed with parafilm and kept inside of a B.O.D. type chamber at $25^{\circ} \mathrm{C}$ and photoperiod of $12 \mathrm{~h}$.

Phytogard ${ }^{\circledR}$ was applied via foliar spraying at concentrations shown in Table 1 at $1 \mathrm{~mL}$ per plant. In the control treatment, plants were sprayed with water only. After six days of product application, the plants were inoculated with $P$. nicotianae. The suspension of zoospores was transferred to the tubes at the concentration of zoospores $1 \times 10^{5} \mathrm{~mL}^{-1}$. The tubes were sealed again with parafilm and kept in a B.O.D chamber under the same conditions as before (Rezende et al., 2020).

After inoculation of $P$. nicotianae, water consumption (transpiration + evaporation) of the seedlings of each treatment was measured by determining the daily difference of tubes + seedlings (Fleischmann et al., 2005).

For each concentration used, there were tubes with seedlings inoculated or noninoculated with $P$. nicotianae. The experiment was installed in a completely randomized design where each concentration was a treatment. Each treatment had six repetitions and each repetition was represented by a tube containing one seedling.

At the end of the experiment, we evaluated the disease incidence and the fresh matter of the shoot and roots of the plants. Later, the plant material was used to carry out the biochemical analyses. 


\subsection{Phenols}

To determine the phenol contend in the roots and leaves of seedlings of tangerine 'Sunki', we used Folin-Ciocalteau. The lyophilized plant tissue $(0.025 \mathrm{~g})$ were macerated in liquid $\mathrm{N}$ and homogenized in $1.5 \mathrm{~mL}$ methanol $80 \%$ and kept on a rotary shaker (100 rpm) for $24 \mathrm{~h}$ at room temperature. Then, the material was centrifuged for $4 \mathrm{~min}$ and $150 \mu \mathrm{L}$ of supernatant was transferred to a new tube and $150 \mu \mathrm{L}$ of the $0.25 \mathrm{~N}$ Folin-Ciocalteau solution was added. The tubes were manually shaken and left to rest for 3 min then $150 \mu \mathrm{L}$ of a $1 \mathrm{~N}$ solution of $\mathrm{Na}_{2} \mathrm{CO}_{3}$ was added. The tubes were submitted again to manual shaking and left to rest for $10 \mathrm{~min}$ at room temperature. Afterward, $1000 \mu \mathrm{L}$ of sterile distilled water was added, the sample was mixed and left to rest for $30 \mathrm{~min}$. Then, we removed $500 \mu \mathrm{L}$ of the sample and absorbance was determined in a spectrophotometer at $725 \mathrm{~nm}$ (Beltrame, 2010).

\subsection{Total protein}

Total protein content was measured according to Bradford (1976). Soluble proteins were extracted by maceration of fresh tissue of seedlings (shoot and root) in the presence of liquid $\mathrm{N}$, followed by the addition of $100 \mathrm{mM}$ potassium phosphate buffer ( $\mathrm{pH}$ 7.5) containing $1 \mathrm{mM}$ EDTA at a rate of $3 \mathrm{~mL}$ of buffer for $1 \mathrm{~g}$ of fresh tissue. The material was centrifuged at $4^{\circ} \mathrm{C}$ for $45 \mathrm{~min}$ at $15000 \mathrm{~g}$ and the supernatant considered as the protein extract that was stored at $-20^{\circ} \mathrm{C}$ for biochemical analyses.

The reagent Protein Assay $\left(\right.$ BioRAD $\left.^{\circledR}\right)$, diluted five times, was used to determine total proteins, according to Bradford (1976). For each sample, we used $1000 \mu \mathrm{L}$ of the reagent solution and $20 \mu \mathrm{L}$ of protein extract diluted seven times. The standard curve was determined by using bovine serum albumin (BSA).

The protein extract was obtained from the experiment installed in a completely randomized design with eight treatments (phosphite concentrations in plants inoculated and non-inoculated with $P$. nicotianae) and five repetitions where each seedling inside in the test tube with water constituted a repetition, totaling 45 seedlings. The results were expressed as $\mathrm{mg}$ of protein $\mathrm{g}$ fresh tissue ${ }^{-1}$.

\subsection{Activity of $\beta-1.3$ glucanase}

To evaluate the activity of $\beta-1.3$ glucanase of seedlings of tangerine 'Sunki', we used the substrate laminarin (Kombrink \& Hahlbrock, 1986) was used. Thus, the protein extract 
prepared in phosphate buffer was used in the following reactions: reaction (1) $150 \mu \mathrm{L}$ of laminarin $\left(4 \mathrm{mg} \mathrm{mL}^{-1}\right)$ dissolved in $100 \mathrm{mM}$ sodium acetate buffer $(\mathrm{pH} 5.0)$ and $100 \mu \mathrm{L}$ protein extract. Control reaction (2) $150 \mu \mathrm{L}$ of laminarin $\left(4 \mathrm{mg} \mathrm{mL}^{-1}\right)$ dissolved in $100 \mathrm{mM}$ sodium acetate buffer (pH 5.0), $100 \mu \mathrm{L}$ protein extract and $125 \mu \mathrm{L}$ of 3.5-Dinitrosalicylic acid (DNSA). Blank reaction (3): $150 \mu \mathrm{L}$ of laminarin (Abeles \& Foence, 1970).

After incubation for $2 \mathrm{~h}$ at $40^{\circ} \mathrm{C}$, the reaction was stopped by adding $125 \mu \mathrm{L}$ of DNSA. Next, the reaction was heated for $5 \mathrm{~min}$ in a water bath at $95^{\circ} \mathrm{C}$. Then, the reaction was cooled in ice bath and 1,125 $\mu \mathrm{L}$ of distilled water was added. After homogenization, the absorbance was measured out at $540 \mathrm{~nm}$ in a spectrophotometer. The enzyme activity was expressed as $\mathrm{mg}$ of glucose released $\mathrm{h}^{-1} \mathrm{mg}$ protein ${ }^{-1}$, based upon a glucose standard curve.

\subsection{Guaiacol peroxidase activity}

To determine the guaiacol peroxidase activity, we used $1.5 \mathrm{~mL}$ of a reaction buffer (100 mL of potassium phosphate buffer $100 \mathrm{mM} \mathrm{pH} 7.5$ with $250 \mu \mathrm{L}$ of guaiacol and $306 \mu \mathrm{L}$ of hydrogen peroxide) and $1.5 \mathrm{~mL}$ of the protein extract obtained as mentioned above (Roncato \& Pascholati, 1998). As blank reaction, we used $1.5 \mathrm{~mL}$ of reaction buffer and 1.5 $\mathrm{mL}$ of extraction buffer (potassium phosphate $100 \mathrm{mM}$ (pH 7.5). The reaction time was one minute and conversion of guaiacol to tetraguaiacol was quantified at $470 \mathrm{~nm}$ in a spectrophotometer.

To calculate the activity, we used $\Delta \mathrm{Abs}_{470 \mathrm{~nm}}$ (difference in absorbance at 0 and $60 \mathrm{sec}$ of sample) and the results were expressed as $\Delta \mathrm{Abs} 470 \mathrm{~nm} \min ^{-1}$ protein $\mathrm{mg}^{-1}$.

\subsection{Phenylalanine ammonia-lyase activity}

The phenylalanine ammonia-lyase (PAL) activity was determined by quantifying the trans-cinnamic acid released from phenylalanine (Umesha, 2006). Thus, $400 \mu 1$ of buffer 25 $\mathrm{mM}$ Tris- $\mathrm{HCl}(\mathrm{pH} 8.8)$ and $500 \mu \mathrm{L}$ of L-phenylalanine $50 \mathrm{mM}$ was added in microcentrifuge tubes and incubated at $40^{\circ} \mathrm{C}$ for $5 \mathrm{~min}$. Subsequently, we added $100 \mu \mathrm{L}$ of protein extract obtained as mentioned above and incubated the reaction mixture $2 \mathrm{~h}$ at $40^{\circ} \mathrm{C}$. To stop the reaction, we added $50 \mu \mathrm{L}$ of $\mathrm{HCl} 5 \mathrm{M}$. The absorbance was measured at $290 \mathrm{~nm}$, which was subtracted from the control mixture absorbance made composed of $500 \mu \mathrm{L}$ of Lphenylalanine, $400 \mu \mathrm{l}$ of buffer $25 \mathrm{mM}$ Tris- $\mathrm{HCl}(\mathrm{pH} 8.8$ ) and $100 \mu 1$ of potassium phosphite 
buffer heated at $40^{\circ} \mathrm{C}$ for $2 \mathrm{~h}$ and added with $50 \mu \mathrm{L}$ of $\mathrm{HCl} 5 \mathrm{M}$. The enzyme activity was expressed as reading in absorbance at $290 \mathrm{~nm} \mathrm{mg}^{-1}$ of protein.

\section{Results and Discussion}

The treatment of seedlings of 'Sunki' tangerine with Phyogard ${ }^{\circledR}$ was promising for disease control and increasing water consumption even in non-inoculated seedlings, based upon results of seedlings treated with the product (Fig. 1). For inoculated plants, there were significant differences among all concentrations compared to the concentration control $(0 \mathrm{~mL}$ $\mathrm{L}^{-1}$ ). In addition, the seedlings that received potassium phosphite at doses of 2 and $5 \mathrm{~mL} \mathrm{~L}^{-1}$ showed significantly higher values of water consumption compared to the control (noninoculated plants and not treated with Phyogard ${ }^{\circledR}$ ) (Fig. 1A). All non-inoculated seedlings, but treated with Phytogard ${ }^{\circledR}$, exhibited statistically higher values compared to the control (Fig. 1B). Although the statistical analysis was carried out only with data for the last assessment day, we can observe that the increase in daily water consumption of seedlings sprayed with potassium phosphite was higher at all concentrations in plants inoculated and non-inoculated with the pathogen.

Figure 1. Water uptake of seedlings of tangerine 'Sunki' treated with Phytogard ${ }^{\circledR}$ (potassium phosphite: $\mathrm{P}_{2} \mathrm{O}_{5}=28 \% ; \mathrm{K}_{2} \mathrm{O}=26 \%$ ) at concentrations of $0 ; 0.5 ; 2$ and $5 \mathrm{~mL} \mathrm{~L}^{-1}$ and inoculated (A) or non-inoculated (B) with Phytophthora nicotianae. The control treatment was not inoculated with $P$. nicotianae. The pathogen was inoculated six days after spraying the product. Lines followed by the same letter do not differ by the Scott-Knott test at 5\% probability in the last assessment. The bars show the standard error $(n=6)$.

A

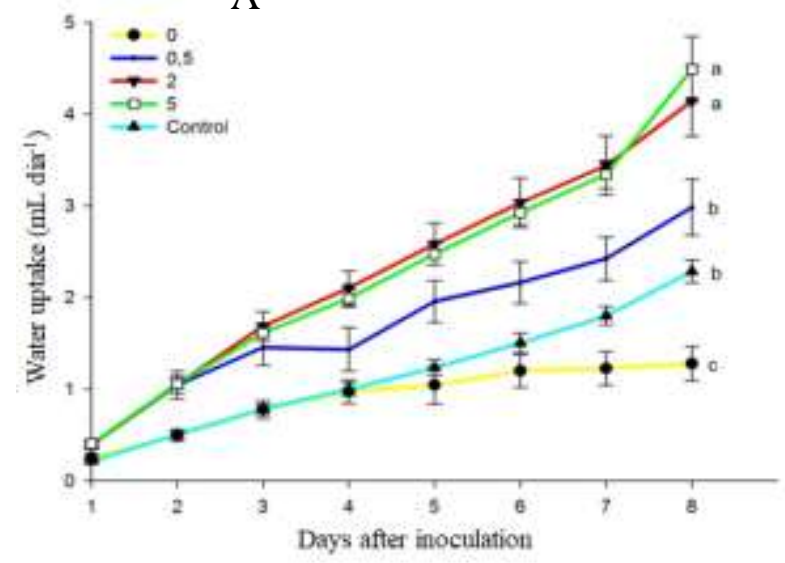

Source: Authors.

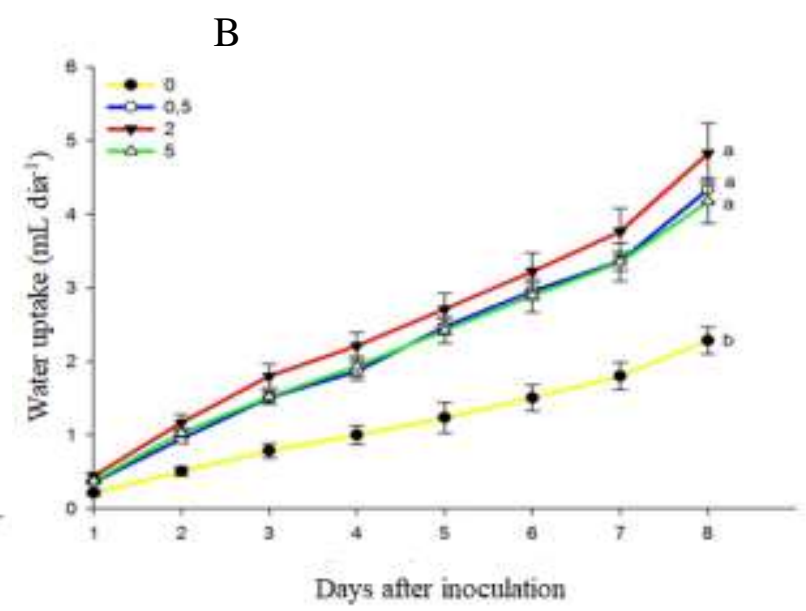


Research, Society and Development, v. 9, n. 10, e7199108992, 2020

(CC BY 4.0) | ISSN 2525-3409 | DOI: http://dx.doi.org/10.33448/rsd-v9i10.8992

The preventive treatment with Phytogard ${ }^{\circledR}$ was effective in the control of $P$. nicotianae in seedlings of tangerine 'Sunki' (Table 2). Although the concentration recommended by the manufacturer for citrus is $2 \mathrm{~mL} \mathrm{~L}^{-1}$, the concentration $0.5 \mathrm{~mL} \mathrm{~L}^{-1}$, four fold smaller, was able to reduce by $84 \%$ the disease incidence and mitigate damages caused by pathogen infection compared to the control. In addition, seedlings sprayed with concentrations 2 and $5 \mathrm{~mL} \mathrm{~L}^{-1}$ showed no incidence of disease.

Table 2. Effect of gummosis (Phytophthora nicotianae) in seedlings of tangerine 'Sunki' treated with Phytogard ${ }^{\circledR}$ (potassium phosphite: $\mathrm{P}_{2} \mathrm{O}_{5}=28 \% ; \mathrm{K}_{2} \mathrm{O}=26 \%$ ) at concentrations of $0 ; 0.5 ; 2$ and $5 \mathrm{~mL} \mathrm{~L}^{-1}$ to evaluate the product protective effect. The pathogen was inoculated six days after spraying the product and evaluation was carried out eight days after inoculation. Each treatment consisted of six repetitions.

\begin{tabular}{ccc}
\hline $\begin{array}{c}\text { Phytogard } \\
\left(\mathrm{mL} \mathrm{L}^{-1}\right)\end{array}$ & \multicolumn{2}{c}{$\begin{array}{c}\text { Disease incidence } \\
(\%)\end{array}$} \\
\cline { 2 - 3 } & Inoculated & Non-inoculated \\
\hline 0 & 100 & 0 \\
0.5 & 16 & 0 \\
2 & 0 & 0 \\
5 & 0 & 0 \\
\hline
\end{tabular}

Source: Authors.

The shoots of seedlings treated with potassium phosphite at all concentrations and inoculated with $P$. nicotianae showed values for fresh matter statistically higher in the aerial parts compared to values obtained in control (Fig. 2). Although there was no significant difference for fresh matter of roots of seedlings treated with Phytogard ${ }^{\circledR}$ and inoculated with the pathogen, we observed that these values increased with higher product concentrations. 
Figure 2. Fresh weigt of shoot (A) and root (B) of seedlings of tangerine 'Sunki' treated with Phytogard ${ }^{\circledR}$ (potassium phosphite: $\mathrm{P}_{2} \mathrm{O}_{5}=28 \% ; \mathrm{K}_{2} \mathrm{O}=26 \%$ ) at concentrations of $0 ; 0.5 ; 2$ and $5 \mathrm{~mL} \mathrm{~L}^{-1}$ inoculated or not with Phytophthora nicotianae. The pathogen was inoculated six days after spraying the product and evaluation was performed eight days after inoculation. Means followed by the same letter do not differ by the Scott-Knott test at 5\% probability. The bars show the standard error $(n=6)$.

A

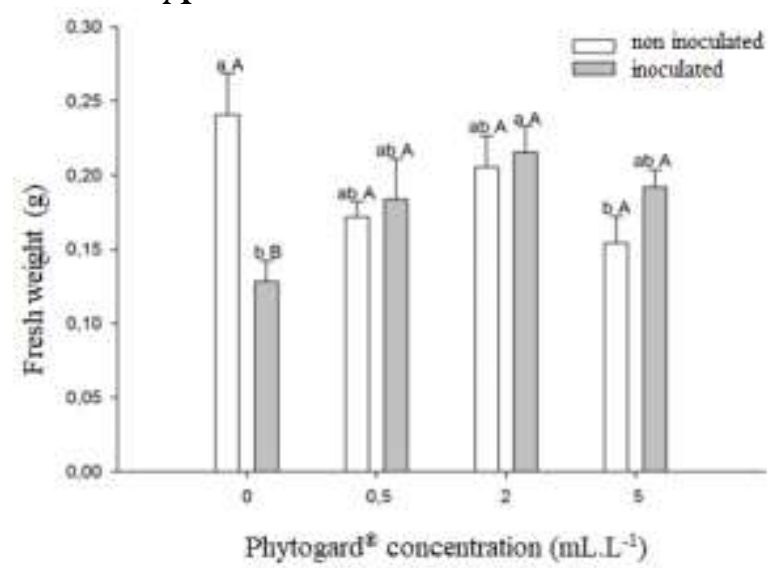

B

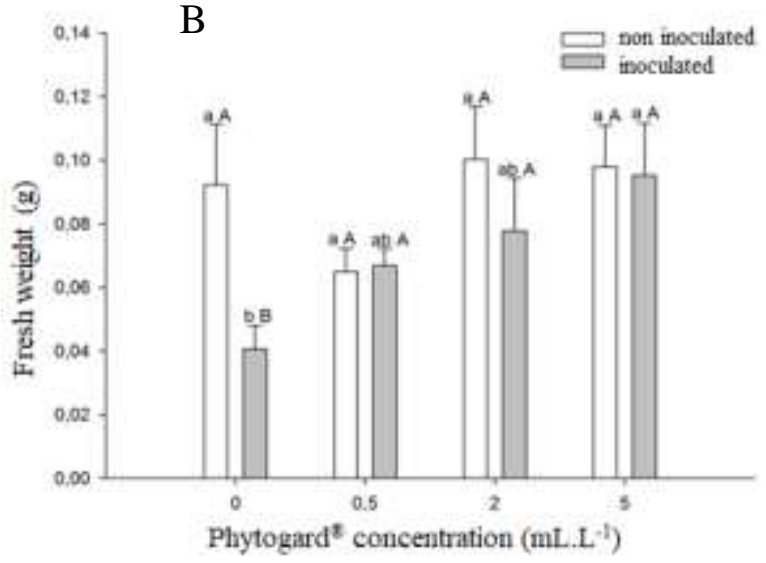

Source: Authors.

Regarding the production of phenolic compounds by the plant shoots, seedlings treated with potassium phosphite at concentrations 0.5 and $2 \mathrm{~mL} \mathrm{~L}^{-1}$ exhibited significant difference among plants inoculated and non-inoculated with the pathogen. The shoots of inoculated seedlings showed higher values compared to the non-inoculated ones (Fig. 3A). On the other hand, only roots of treated seedlings at concentrations 0.5 and $2 \mathrm{~mL} \mathrm{~L}^{-1}$ of Phytogard ${ }^{\circledR}$ showed statistical difference between inoculated and non-inoculated plants. The highest values of total phenols were found in roots of seedlings not inoculated with P. nicotianae (Fig. 3B). 
Figure 3. Total phenols of shoots $(\mathrm{A})$ and roots $(\mathrm{B})$ of seedlings of tangerine 'Sunki' treated with Phytogard ${ }^{\circledR}$ (potassium phosphite: $\mathrm{P}_{2} \mathrm{O}_{5}=28 \% ; \mathrm{K}_{2} \mathrm{O}=26 \%$ ) at concentrations $0 ; 0.5 ; 2$ and $5 \mathrm{~mL} \mathrm{~L}^{-1}$ inoculated or not with Phytophthora nicotianae. The pathogen was inoculated six days after spraying the product and evaluation was carried out eight days after inoculation. Bars of the same color followed by the same lowercase letters do not differ. Bars belonging to the same dose followed by the same capital letters do not differ by the Tukey test at 5\% probability. The bars show the standard error $(n=5)$.

A

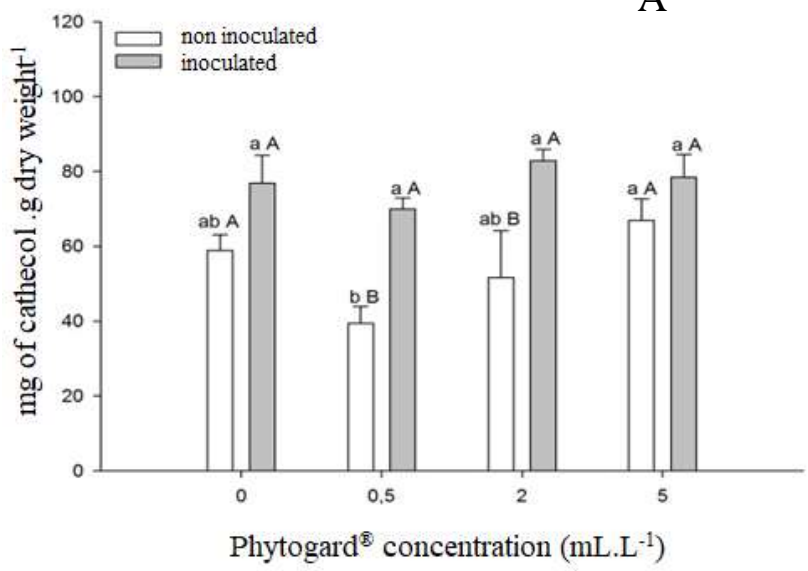

B

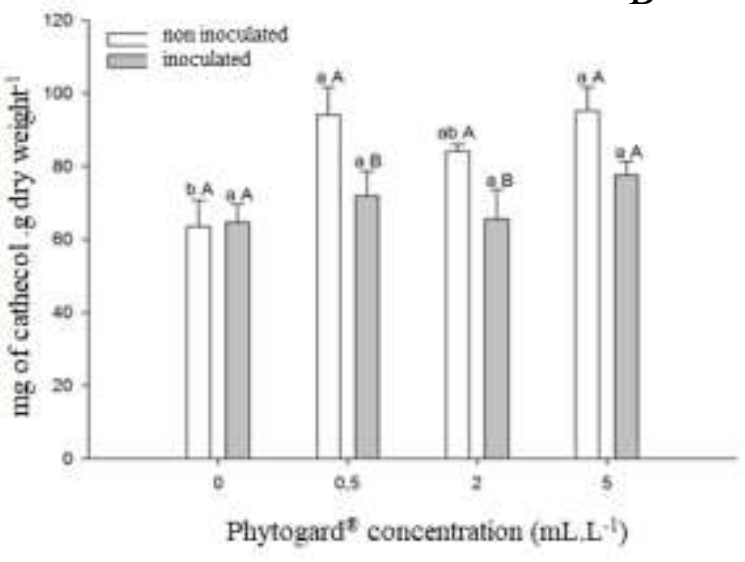

Source: Authors.

Regarding total protein production by the plant shoots, there were a significant differences among inoculated and non-inoculated plants only in plants that were not treated with Phytogard ${ }^{\circledR}$ and inoculated plants obtained higher values compared to the non-inoculated ones (Fig. 4A). In the shoots, the differences between total protein values were significant only in plants inoculated with the pathogen and only concentration $5 \mathrm{~mL} \mathrm{~L}^{-1}$ differed from the control (dose $0 \mathrm{~mL} \mathrm{~L}^{-1}$ ). The total protein extracted from the roots of seedlings showed a significant difference between inoculated and non-inoculated plants at doses 0 and $5 \mathrm{~mL} \mathrm{~L}^{-1}$ and inoculated plants showed higher values. Similar values were found in inoculated seedlings with higher concentrations of total proteins in roots of seedlings treated with Phytogard $^{\circledR}$ at doses control and $5 \mathrm{~mL} \mathrm{~L}^{-1}$. When we analyze the inoculation factor separately, we observed that roots of seedlings inoculated with $P$. nicotianae showed higher total protein values when compared to the non-inoculated ones (Fig. 4B). 
Figure 4. Total protein of the shoots (A) and roots (B) of seedlings of tangerine 'Sunki' treated with Phytogard ${ }^{\circledR}$ (potassium phosphite: $\mathrm{P}_{2} \mathrm{O}_{5}=28 \% ; \mathrm{K}_{2} \mathrm{O}=26 \%$ ) at concentrations of0; $0.5 ; 2$ and $5 \mathrm{~mL} \mathrm{~L}^{-1}$ inoculated or not with Phytophthora nicotianae. The pathogen was inoculated six days after spraying the product and evaluation was carried out 13 days after inoculation. Bars of the same color followed by the same lowercase letters do not differ. Bars belonging to the same dose followed by the same capital letters do not differ by the Tukey test at $5 \%$ probability. The bars show the standard error $(n=5)$.

A

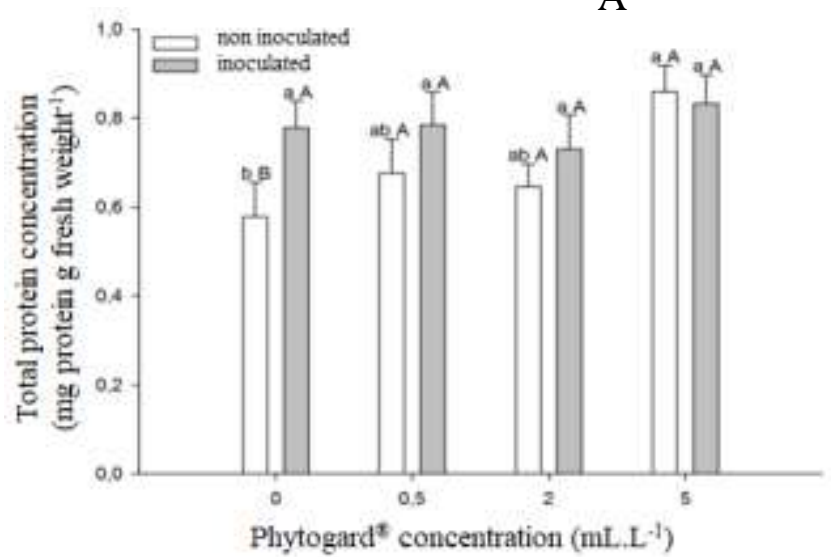

B

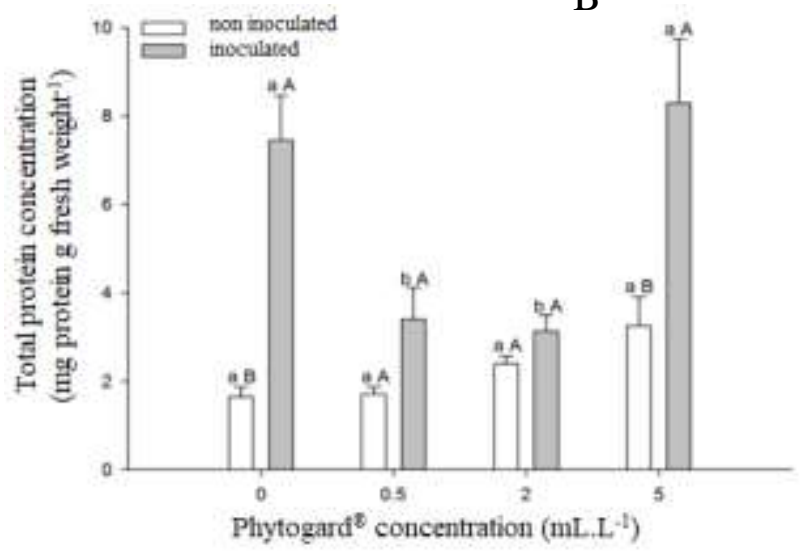

Source: Authors.

The activity of the enzyme $\beta-1.3$ glucanase of shoots of seedlings treated with potassium phosphite showed a significant difference between inoculated and non-inoculated plants only at dose $0.5 \mathrm{~mL} \mathrm{~L}^{-1}$ (Fig. 5A). Statistical differences between the concentrations were observed only in plants inoculated and concentrations control and $0.5 \mathrm{~mL} \mathrm{~L}^{-1}$ and presented higter values compared to concentrations 2 and $5 \mathrm{~mL} \mathrm{~L}^{-1}$. The activity of this enzyme in the tissue of roots of seedlings was statistically different between inoculated and non-inoculated plants at doses control and $5 \mathrm{~mL} \mathrm{~L}^{-1}$ with smaller values than the other treatments. Significant differences in the activity of $\beta-1.3$ glucanase in roots of seedlings treated with different concentrations of Phytogard ${ }^{\circledR}$ were only observed in inoculated plants where plants treated with the product at concentration $2 \mathrm{~mL} \mathrm{~L}^{-1}$ showed higter values for the activity of this enzyme (Fig. 5B). 
Figure 5. $\beta-1.3$ glucanase activity of shoots (A) and roots (B) of seedlings of tangerine 'Sunki' treated with Phytogard ${ }^{\circledR}$ (potassium phosphite: $\mathrm{P}_{2} \mathrm{O}_{5}=28 \% ; \mathrm{K}_{2} \mathrm{O}=26 \%$ ) at concentrations of $0 ; 0.5 ; 2$ and $5 \mathrm{~mL} \mathrm{~L}^{-1}$ inoculated or not with Phytophthora nicotianae. The pathogen was inoculated six days after spraying the product and evaluation occurred 13 days after inoculation. Bars with the same color followed by lowercase the same letters do not differ. Bars belonging to the same dose followed by the same capital letters do not differ by the Tukey test at $5 \%$ probability. The bars show the standard error $(n=5)$.

A

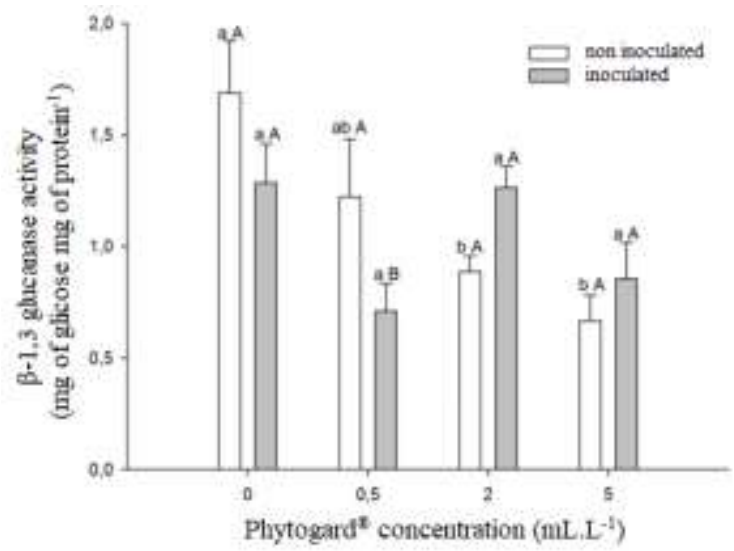

B

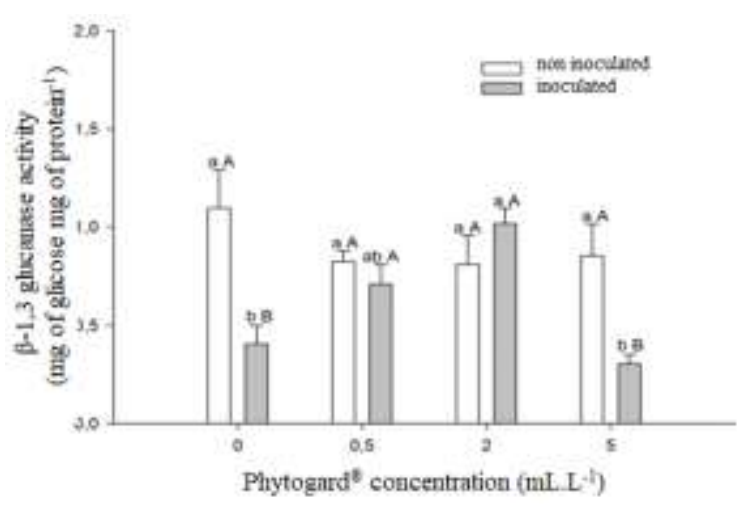

Source: Authors.

There was no significant difference in the activity of guaiacol peroxidase enzyme in tissues of shoots of seedlings treated with different concentrations of Phytogard ${ }^{\circledR}$ and inoculated with $P$. nicotianae (Fig. 6A). On the other hand, the activity of this enzyme in tissues of roots of seedlings was different at all concentrations of potassium phosphite used, with the exception of $2 \mathrm{~mL} \mathrm{~L}^{-1}$ when we compare inoculated and non-inoculated plants (Fig. 6B). Significant differences between treatments with different concentrations of phosphite were only observed in inoculated plants where the concentration of $5 \mathrm{~mL} \mathrm{~L}^{-1}$ showed lower values compared to the others. 
Figure 6. Guaiacol peroxidase activity of shoots (A) and roots (B) of seedlings of tangerine 'Sunki' treated with Phytogard ${ }^{\circledR}$ (potassium phosphite: $\mathrm{P}_{2} \mathrm{O}_{5}=28 \% ; \mathrm{K}_{2} \mathrm{O}=26 \%$ ) at concentrations of $0 ; 0.5 ; 2$ and $5 \mathrm{~mL} \mathrm{~L}^{-1}$ inoculated or not with Phytophthora nicotianae. The pathogen was inoculated six days after spraying the product and evaluation was performed 13 days after inoculation. Bars with the same color followed by the same lowercase letters do not differ. Bars belonging to the same dose followed by the same capital letters do not differ by the Tukey test at $5 \%$ probability. The bars show the standard error $(n=5)$.

A

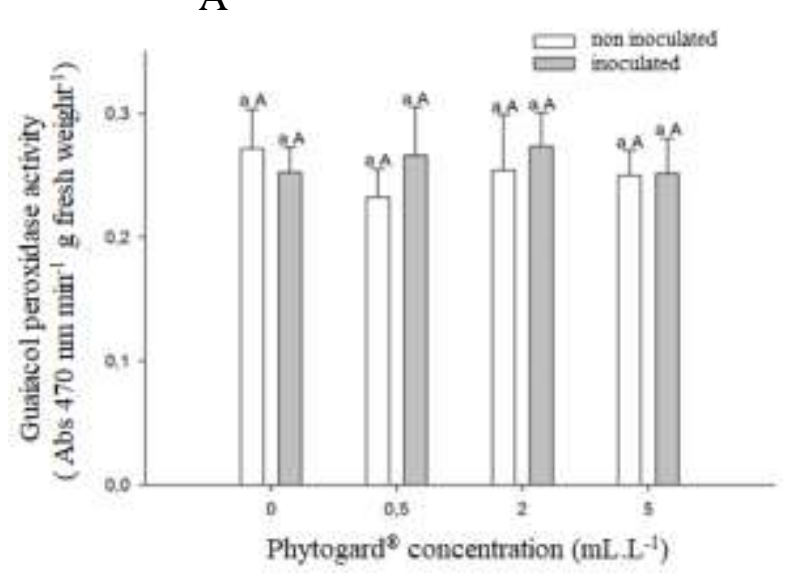

B

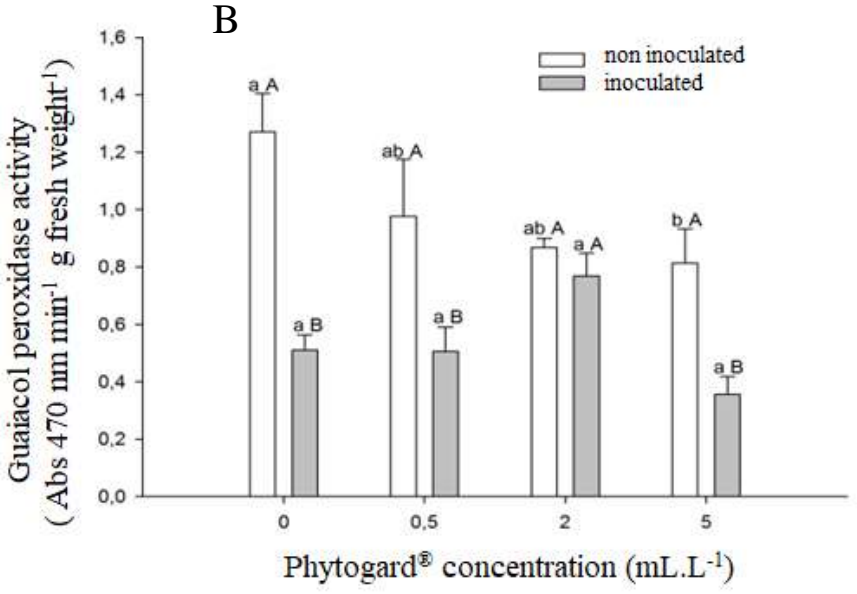

Source: Authors.

Although there is no statistical difference, higher activity of phenylalanine ammonialiase enzyme was observed in the tissues of inoculated plants when compared to the noninoculated ones in relation to the shoots of seedlings. Likewise, there was no significant difference between the values of the enzyme activity in plants that received different concentrations of phosphite (Fig. 7A). Regarding root tissues, higher enzymatic activity occurred in plants not inoculated with $P$. nicotianae at concentrations of 0 and $5 \mathrm{~mL} \mathrm{~L}^{-1}$ of Phytogard ${ }^{\circledR}$ when compared to the non-inoculated ones (Fig. 7B). Among the non-inoculated, statistically higher value was found only in plants that did not receive treatment with phosphite, while among the inoculated there was no statistical difference between the plants that received different concentrations of the product. 
Figure 7. Phenylalanine ammonia-lyase activity of aerial part (A) and roots (B) of seedlings of tangerine 'Sunki' treated with Phytogard ${ }^{\circledR}$ (potassium phosphite: $\mathrm{P}_{2} \mathrm{O}_{5}=28 \% ; \mathrm{K}_{2} \mathrm{O}=$ $26 \%$ ) at concentrations of $0 ; 0.5 ; 2$ and $5 \mathrm{~mL} \mathrm{~L}^{-1}$ inoculated or not with Phytophthora nicotianae. The pathogen was inoculated six days after spraying the product and evaluation was conducted 13 days after inoculation. Bars with the same color followed by the same lowercase letters do not differ. Bars belonging to the same dose followed by the same capital letters do not differ by the Tukey test at $5 \%$ probability. The bars show the standard error $(\mathrm{n}=$ $5)$.
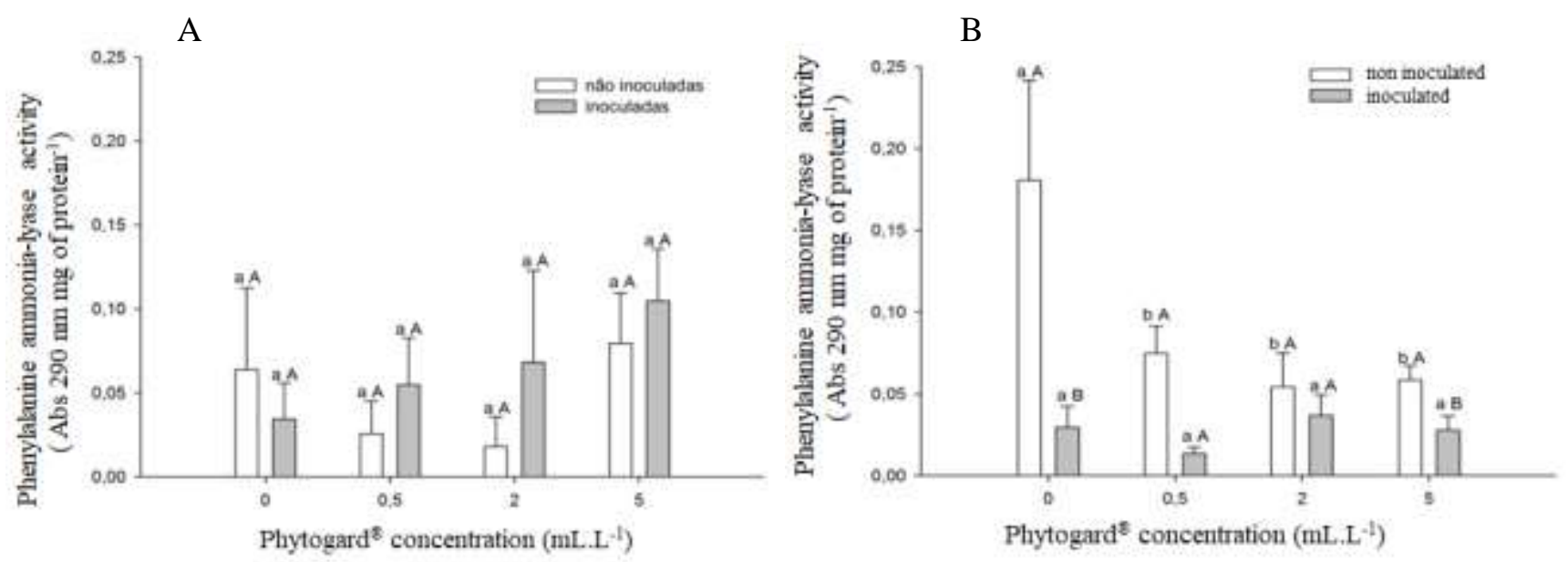

Source: Authors.

Studies observing resistance induction promoted by the application of phosphites, as far as we know, had their first results published by Gottstein and Kuć (1989), Mucharromah and Kuć (1991) and Reuveni, Agapov and Reuveni (1994).

Results using potassium phosphite in the Phytophthora nicotianae-citrus pathosystem are scarce in the literature. Most of the work involves the potato - Phytophthora infestans pathosystem. Olivieri et al. (2012) reported that with the application of potassium phosphite results in molecular modifications in potato tuber periderm and cortex, higher amount of pectin, increase in the content and/or activity of polygalacturonase and proteinase inhibitor as well as a new isoform of chitinase.

Ohammadi et al. (2019) carried out a study with the use of potassium phosphite (KPhi) on biochemical contents and enzymatic activities of Chinese Potatoes inoculated with Phytophthora infestans. The results demonstrated that the applications of KPhi on leaves resulted in postharvest tubers with notably decreased disease symptoms after infection with two $P$. infestans pathogen strains. Tuber slices from KPhi applied plants following infection 
showed a significant increase in the contents of phytoalexins and phenols. PR-3 activities were induced by KPhi and wounding with the highest level at 48 hours, and the activities of PR-2 were not significantly induced by KPhi or wounding. The findings of the authors suggested that KPhi improves resistance in tubers against the pathogen infection via activation of defense responses, such as defense biochemical compounds, pathogenesisrelated enzymes and antioxidant enzyme activities. Our results also demonstrate disease control, however, there is no evidence of resistance induction based on the analyzes performed.

A study carried out by Machinandiarena et al. (2012) in the potato pathosystem - $P$. infestans describe as earlier callose deposition, enhanced on expression of StNPR1 and StWRKY1 in response to KPhi treatment. In contrast, StIPII was down regulated in both KPhi- and water-treated leaves, until $48 \mathrm{~h}$ after infection with $\mathrm{Pi}$, suggesting that the regulation of this gene could be independent of the KPhi treatment. The results indicate that KPhi primes the plant for an earlier and more intense response to infection and that salicylic acid (SA) would mediate this response.

Rey-Burusco, Daleo and Feldman (2019) carried out a study aimed to gain an insight into the complex mechanisms of action of KPhi. The authors performed a sequencing analysis to determine changes in miRNA expression and analyzed their targets in potato leaves treated with KPhi. In summary, the authors provided evidence that the amplitude of responses associated with KPhi treatment can be, at least in part, explained by the diversity of miRNAs that are differentially expressed, once the study showed 25 miRNAs were differentially expressed after KPhi treatment. A prediction of miRNA targets showed genes related to pathogen resistance, transcription factors, and oxidative stress. Further characterization of these miRNAs and their target genes might help to elucidate the molecular mechanisms underlying KPhi-induced resistance.

Other pathosystems have been reported with positive effects on disease control with the application of potassium phosphite as cucumber - Colletotrichum lagenarium (Orober, Siegrist \& Buchenauer, 2002), mango - Ceratocystis fimbriata (Araujo et al., 2015), soybean and maize - Pratylenchus brachyurus (Dias-Arieria et al., 2012) with the main defense responses associated with microscopic defense responses, like tyloses, cell death similar to a hypersensitive response (HR), rapid generation of superoxide and hydrogen peroxide, increase in salicylic acid (SA) levels, higher concentrations of alkaloids (theobromine and 7methylxanthine) and phenolic compounds (catechin, epicatechin, epigallocatechin, gallic acid, 
myricetin, p-coumaric acid, p-hydroxybenzoic acid, phloridzin, sinapinic acid, and salicylhydroxamic acid), as well as, induction of phenylpropanoid pathway.

\section{Conclusion}

The results show that the potassium phosphite exhibited potential for the control of Phytophthora nicotianae in seedlings of tangerine 'Sunki'. However, it is not possible to conclude,e based upon the biochemical analyses that this control occurs through resistance induction.

The possibility of using the Phytogard® in preventive treatments against Phytophthora nicotianae in citrus seedlings seems to be interesting and advantageous. However, experiments in field conditions should be carried out in order to identify the dose and frequency of application of phosphite that should be used by the producer and to expand the tools available for the management of gummosis in citrus orchards.

\section{Acknowledgements}

To Stoller do Brasil for supplying the product for the study, to Coordination for the Improvement of Higher Education Personnel (CAPES) and to National Council for Scientific and Technological Development $(\mathrm{CNPq})$ for the scholarship, and Federal Institute of Education, Science and Technology of South of Minas Gerais (IFSULDEMINAS) for supporting the publication of this study.

\section{References}

Abeles, F. B., \& Foence, L. E. (1970). Temporal and hormonal control of $\beta$-1,3-glucanase in Phaseolus vulgaris. Plant Physiology, 45, 305-400.

Araujo, L., Silva Bispo, W. M., Rios, V. S., Fernandes, A. S., \& Rodrigues F. A. (2015). Induction of the Phenylpropanoid Pathway by Acibenzolar-S-Methyl and Potassium Phosphite Increases Mango Resistance to Ceratocystis fimbriata Infection. Plant Disease, 99, 447-459. 
Beltrame, A. B. (2010). Interação Phytophthora nicotianae - porta enxerto de citros (Tangerina Sunki e Citrumelo Swingle): Efeito no sistema radicular, aspectos fisiológicos e bioquímicos. Tese de Doutorado, Escola Superior de Agricultura "Luiz de Queiroz", Universidade de São Paulo. Piracicaba, São Paulo.

Bradford, M. M. (1976). A rapid and sensitive method for the quantification of microgram quantities of protein utilizing the principle of protein-dye binding. Analytical biochemistry, $72,248-254$.

Carswell, S. C., Grant, B. R., Theodorou, M. E., Harris, J., Niere, J. O., \& Plaxton, W. C. (1996). The fungicide phosphonate disrupts the phosphate starvation response in Brassica nigra seedlings. Plant Physiology, 110, 105-110.

Cohen, M. D., \& Coffey, M. D. (1986). Systemic fungicides and the control of oomycetes. Annual Review Phytopathology, 24, 311-338.

Dalio, R. J. D., Ribeiro Junior, P. M., Resende, M. L. V., Silva, A. C., Blumer, S., Pereira, V. F., Osswald, W., \& Pascholati, S. F. (2012). O triplo modo de ação dos fosfitos em plantas. In: Luz, W. C. (Org.). Revisão Anual de Patologia de Plantas, 20, 206-242.

Dalio, R. J. D., Fleischmann, F., Humez, M., \& Wolfgang, O. (2014). Phosphite protects Fagus sylvatica seedlings towards Phytophthota plurivora via local toxicity, priming and facilitation of pathogen recognition. Plos One, 9, 1-10.

Dias-Arieria, C. R., Marini, P. M., Fontana, L. F., Roldi, M., \& Silva, T. R. B. (2012). Effect of Azospirillum brasilense, Stimulate ${ }^{\circledR}$ and Potassium Phosphite to control Pratylenchus brachyurus in soybean and maize. Nematropica, 42, 170-175.

Feichtenberger, E., Bassanezi, R. B., Spósito, M. B., \& Belasque Júnior, J. (2005). Doenças dos Citros. In: Kimati, H., Amorim, L., Rezende, J. A. M., Bergamin Filho, A., \& Camargo, L. E. A. (Ed.). Manual de Fitopatologia (pp. 239-269). São Paulo: Editora Agronômica Ceres. 
Fleischmann, F., Koehl, J., Portz, R., Beltrame, A. B., \& Osswald, W. (2005). Physiological changes of Fagus sylvatica seedlings infected with Phytophthora citricola and the contribution of its elicitin "Citricolin” to pathogenesis. Plant Biology, 6, 650-658.

Forster, H., Adaskaveg, J. E., Kim, D. H., \& Stanghellin, M. E. (1998). Effect of phosphite on tomato and peper plants on susceptibility of peper to Phytophthora root and crown rot in hydroponic culture. Plant Disease, 82, 1165-1170.

Fundecitrus (2004). Prevenção começa na muda. Revista do Fundecitrus, 123, 12-13.

Graham, J. H., \& Timmer, L. W. (1994). Phytophthora diseases of Citrus. Retrieved from https://ufdc.ufl.edu/IR00004644/00001.

Gottstein, H. D., \& Kuć, J. (1989). Induction of systemic resistance to anthracnose in cucumber by phosphates. Phytopathology, 79, 176-179.

Guest, D., \& Grant, B. R. (1991). The complex action of phosphonates as antifungal agents. Biological Review, 66, 159-187.

Kombrink, E., \& Hahlbrock, K. (1986). Responses of cultured parsley cells to elicitors from phytopathogenic fungi. Plant Physiology, 81, 216-221.

Machinandiarena, M. F., Lobato, M. C., Feldman, M. L., Daleo, G. R., \& Andreu, A. B. (2012). Potassium phosphite primes defense responses in potato against Phytophthora infestans. Journal of Plant Physiology, 169, 1417-1424.

Mucharromah, E., \& Kuć, J. (1991). Oxalate and phosphates induce systemic resistance against diseases caused by fungi, bacteria and viruses in cucumber. Crop Protection, 10, 265270.

Nascimento, A. R., Fernandes, P. M., Rocha, M. R., \& Silva, E. A. (2008). Fontes de fosfito e acibenzolar-s-metil no controle de doenças e produtividade do tomateiro. Bioscience Journal, 24, 53-59. 
Ohammadi, M. A., Zhang, Z., Xi, Y., Han, H., Lan, F., Zhang, B., Wang, P., \& Ruski, G. (2019). Effects of potassium phosphite on biochemical contents and enzymatic activities of Chinese Potatoes inoculated by Phytophthora infestans. Applied Ecology and Environmental Research, 17, 4499-4514.

Olivieri, F. P., Feldman, M. L., Machinandiarena, M. F., Lobato, M. C., Caldiz, D. O., Daleo, G.R., \& Andreu, A. B. (2012). Phosphite applications induce molecular modifications in potato tuber periderm and cortex that enhance resistance to pathogens. Crop Protection, 32, 16.

Orober, M., Siegrist, J., \& Buchenauer, H. (2002). Mechanisms of Phosphate-induced Disease Resistance in Cucumber. European Journal of Plant Pathology, 108, 345-353.

Reuveni, R., Agapov, V., \& Reuveni, M. (1994). Foliar spray of phosphates induces groth increase and systemic resistance to Puccinia sorghi in maize. Plant Pathology, 43, 245-250.

Rey-Burusco, M. F., Daleo, G. R., \& Feldman, M. L. (2019). Identification of potassium phosphite responsive miRNAs and their targets in potato. PlosOne, 12, 1-15.

Rezende, D. C., Brandão, D. F. R., Brand, S. C., Blumer, S., Pascholati, S. F., \& Mafra, N. M. (2020). Fosfito de potássio e suas implicações no controle de Phytophthora plurivora em faia. Research, Society and Development, 9 (10), e5629108824. https://doi.org/10.33448/rsdv9i10.8824.

Roncato, M. C., \& Pascholati, S. F. (1998). Alterações na atividade e no perfil eletroforético da peroxidase em folhas de milho (Zea mays) e sorgo (Sorghum bicolor) tratadas com levedura (Saccharomyces cerevisae). Scientia Agricola, 55, 395-402.

Schroetter, S., Angeles-Wedler, D., Kreuzig, R., \& Schnug, E. (2006). Effects of phosphite on phosphorus supply and growth and growth of corn (Zea mays). Landbauforschung Volkenrodxe, 56, 87-99.

Umesha, S. (2006). Phenylalanine ammonia lyase activity in tomato seedlings and its relationship to bacterial canker disease resistance. Phytoparasitica, 34, 68-71. 
Varadarajan, D. K., Karthikeyan, A. S., Matilda, P. D., \& Raghothama, K. G. (2002). Phosphite, an analog of phosphate suppresses the coordinated expression of genes under phosphate starvation. Plant Physiology, 129, 1232-1240.

\section{Percentage of contribution of each author in the manuscript}

Dalilla Carvalho Rezende - $22 \%$

Dayson Fernando Ribeiro Brandão - 18\%

Simone Cristiane Brand - 16\%

Silvia Blumer $-16 \%$

Sérgio Florentino Pascholati - 18\%

Natália Moreira Mafra - 10\% 